\title{
Vi kommer ikke ud af os selv
}

\section{Menneskets indesluttethed og forløsningen udefra som et grundmotiv i den unge Løgstrups prædikener}

\author{
Lektor, ph.d. \\ David Bugge
}

\begin{abstract}
Based on the sermons of K. E. Løgstrup as a young vicar, the article reflects on a thought-figure that is also characteristic of his later writings: man withdraws into himself, and redemption must come from the outside. This self-imprisonment is, not least, due to man's self-important 'opinions', whether ethical or religious, that pre-vent a real interpersonal encounter. However, according to Løgstrup, also any ethics of duty implies a (Pharisaic) 'self-doubling'. Hence the ethical demand is not a de-mand for ethics, as is often assumed, but a demand for love. In this way, the notion that 'doing one's duty' or 'standing firm' is the essence of life, as suggested by the Løgstrup-inspired psychologist Svend Brinkmann (in his otherwise well-placed cri-tique of the 'religion of the self'), neglects the very core of Løgstrup's thinking. Ul-timately this notion implies a self-assertion and, from a Løgstrupian point of view, misses the sense of immediacy, of radical interdependence (i.e., with no dichotomy between self love and neighbour love), and of redemption coming from the outside when somebody else holds $m y$ life in his or her hand.
\end{abstract}

Keywords: K. E. Løgstrup - sermons - opinions - Tom Kristensen critique of ethics - idealism - self-imprisonment - hand-metaphor Svend Brinkmann - ethics of duty - doubling - immediacy - radical interdependence - redemption from the outside - self-assertion - Pharisaism - mercy - love - Søren Kierkegaard - Henrik Ibsen

Ingen af de tre store såkaldte aarhusteologer K.E. Løgstrup, P.G. Lindhardt og Johannes Sløk brød sig om at være en del af en bevægelse; alle havde de - også i deres opgør med teologiske grupperinger - et skarpt blik for den eksklusivitet og selvhøjtidelighed, der uvægerligt klæber til menneskelige (menings)fællesskaber. En samlebetegnelse som 'aarhusteologi' må således have været dem inderligt imod, også uafhængigt af deres mere eller mindre fagligt funderede indbyrdes uoverensstemmelser. Den ældste iblandt dem, Løgstrup, som det skal handle om i det følgende, hæftede gerne glosen 'trivialitet' på en sådan menneskelig hang til at hente identitet fra et gruppefællesskab.

Løgstrup var da også nået frem til sin vigtigste teologisk-antropologiske grundkonception, allerede inden han på den skelsættende dato 
29. august 1943 flyttede til Aarhus for at tiltræde stillingen som professor i etik og religionsfilosofi ved det nyoprettede teologiske fakultet. Gennem de syv år for Lea, han forud havde trællet som sognepræst i Sandager-Holevad på Fyn, udfolder han nemlig i sine prædikener den tankefigur, der bliver bærende i hans senere værk: at mennesket lukker sig inde i sig selv, og at befrielsen må komme udefra. Det er denne tankefigur i prædikenerne og dens videreliv i Løgstrups senere værk, der skal forfølges her, idet det samtidig vil blive vist, hvordan den hos Løgstrup er forbundet med en kritik af selvfordoblingen, bl.a. i pligtetikkens udgave. ${ }^{1}$

Når det således skal dreje sig om Løgstrups før-aarhusianske prædikener (med løbende udblik til det senere forfatterskab), skal en enkelt ting imidlertid forudskikkes. Med en let drejning af den berømte programerklæring i forordet til Opgør med Kierkegaard er interessen i det følgende rettet mod "tendensen og konsekvensen" i Løgstrups prædikener, ikke mod, hvad "han - også - har sagt". ${ }^{2}$ Mht. de steder, hvor Løgstrup som prædikant (eller senere i forfatterskabet) ikke er fuldt på højde med sin egen teologi, kan man passende besinde sig på hans opfordring fastelavnssøndag 1937 til de (i reglen vist yderst få) fremmødte kirkegængere om altid aktivt at tage stilling til præstens tale og kritisk spørge, om han denne gang blot forfaldt til "mennesketanker, der forvrængede Guds ord" (38).

\section{Meninger}

Samme år (1930) som Københavns Universitet udskrev en prisopgave med den fængende titel En Fremstilling og Vurdering af Max Scheler's "Der Formalismus in der Ethik und die materiale Wertethik", som den nybagte cand.theol. K.E. Løgstrup valgte at besvare, udkom periodens måske mest skelsættende roman herhjemme: Tom Kristensens

1. Løgstrups vigtigste prædikener fra perioden foreligger i Predikener fra SandagerHolevad, udg. Elsebeth Diderichsen \& Ole Jensen (København: Gyldendal 1995), der er forsynet med oplysende noter og efterord; hvor intet andet fremgår, er sidehenvisninger i det følgende til dette værk, hvis delvise modernisering af ortografien bibeholdes. Øvrige prædikener fra Løgstrups hånd er tilgængelige på Løgstrup Arkivet, Aarhus Universitet. - Det er teologien i prædikenerne og den dermed forbundne antropologi, det her kommer an på; hvad der i øvrigt måtte være at sige om prædikenerne i henseende til stil, retorik, billedsprog, historisk kontekst osv., falder uden for artiklens rammer.

2. K.E. Løgstrup, Opgør med Kierkegaard (Aarhus: Klim 2013 (1968)), 9. Ved Løgstrups værker refereres der til udgaven i Løgstrup Biblioteket, hvor en sådan foreligger, ellers til førsteudgaven. 
Harvark. En roman, der - prisafhandlingens kvaliteter ufortalte må siges at være en kende mere velskrevet og lidt mere af en page turner end den senere aarhusteologs akademiske svendestykke. Og måske nok så meget i tråd med dennes efterfølgende forfatterskab. ${ }^{3}$

Første hoveddel i Harvark bærer titlen "Mellem meninger"; og romanen udgør én lang hudfletning af det etisk-politiske meningstyranni, der selvhævdende trivialiserer og blokerer for livet. Hovedpersonen Ole Jastrau, der fra filosofikum kun husker én disciplin med større afsky end logikken, nemlig etikken, er ved at kvæles i folks evindelige selvpositionering; og han erklærer slet og ret: "alle meninger er gale!” - en formulering, vi i beslægtet form genfinder i Løgstrups prædikener fra samme årti $(130){ }^{4}$

Netop leden ved meninger inspirerer hen imod romanens slutning Jastrau til følgende lille strofe, der giver mindelser om Løgstrups senere trivialitetsanalyse:

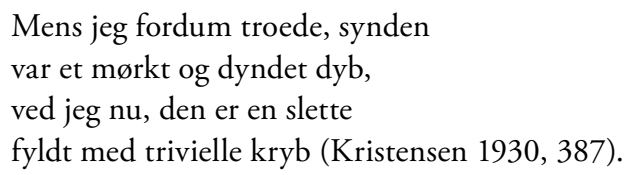

Akkurat på denne slette trives de selvhøjtidelige, trivielle meninger. Og mon ikke man aner Tom Kristensen selv bag de ord, der falder, da den hærværks-smægtende Steffensen til sidst er konverteret til katolicismen: "Sub specie æterni er ingen til grin eller alle til grin" (Kristensen 1930, 430). Evigheden nivellerer alle menneskelige forskelle - de forskelle, vi ellers ihærdigt søger at etablere, ikke mindst i kraft af vores meninger. Hvilket leder os tilbage til Løgstrup.

Hvad vil det sige at være voksen? spørger Løgstrup i en prædiken fra 1938. At være voksen, svarer han, er, blandt meget andet, at føle sig såre vigtig. Alt - fra vores geschæft til vores meninger - belægges med en betydningsfuldhed, så vi kan hævde os og fortrænge vores begrænsning. Hvorfra ved Løgstrup det? Det ved han pudsigt nok fra barnets leg. For når barnet leger voksen, sker det netop ved at se meget vigtig ud, ved at tale med alvorlig stemme og anlægge højtidelig mine. Denne attitude har barnet "afluret os" (86). Men hermed, fortsætter prædikanten, har vi lukket os inde med vores egen vigtighed. Vores alvorstunge og selvhøjtidelige meninger gør os, som det hedder

3. K.E. Løgstrup, En Fremstilling og Vurdering af Max Scheler's "Der Formalismus in der Ethik und die materiale Wertethik", udg. Bjørn Rabjerg (Aarhus: Klim 2016).

4. Tom Kristensen, Harvark (København: Gyldendal 1930), 10. 
et par år senere, til "selvbegloende stakler”, fortabt i den evindelige "selvfordobling" (150f). ${ }^{5}$

Undertiden, hører man fra prædikestolen i 1937, antager meningerne skikkelse af etisk eller politisk idealisme, der én gang for alle mener at kunne løse samtlige problemer. I flæng anføres en række eksempler: "National-socialisme, Oxford-bevægelse eller Tredie standpunkt" (80). At handle i det godes tjeneste er nemlig overalt drivkraften for idealisten, hvad enten det drejer sig om den kristne etiker, der, med en langt senere formulering, altid sidder "med Vorherre som trumfes i baghaanden", ${ }^{\circ}$ eller om rigskansleren syd for grænsen, "Europas største idealist”, som Løgstrup benævner ham i et samtidigt kollegiehæfte. ${ }^{7}$ I marts 1938, kun en uge efter Anschluss, får kirkegængerne i Sandager-Holevad således følgende svada med hjem:

Den mand, der organiserer jødeforfølgelser er lige så overbevist om at udøve en hellig mission - er lige så overbevist om at gøre noget godt og nødvendigt som den kristne missionær i det inderste af Afrika er overbevist derom, når han forkynder evangeliet for de indfødte (92).

Løgstrup har rimeligvis været på rejse med Joseph Conrad (en af hans yndlingsforfattere) til Afrikas - og menneskehjertets - inderste mørke. Og fra det senere forfatterskab genkender vi både kritikken af ideologien, "tankens ligeløb”, som han nu benævner det, ${ }^{8}$ og det skarpe blik for alvorens og etikkens janusansigt; som det hedder mange år senere i Løgstrups veloplagte opposition ex auditorio ved Jens Holger Schjørrings disputatsforsvar i 1979: "Hvorfor blev Tyskland nazistisk? Af alvor, af moral, af samvittighed!"

Til andre tider, lyder det i en prædiken fra 1943, antager meningerne snarere skikkelse af dogmatisk rettroenhed ('kristelig korrekthed', som Løgstrup kalder det), altså religiøs idealisme, med dertil hørende læresætninger, der ikke er stort andet end tomme hylstre (254). Og at sådanne "katekismus-meninger" (85) også i rigt mål flyder fra landets prædikestole, fremgår af Løgstrups samtidige opgør med homiletikken hos danske barthianere (bl.a. i skikkelse af en senere Aarhus-

5. For en fyldigere udfoldelse af Løgstrups syn på den voksnes selvhøjtidelige alvor til forskel fra barnets tillidsfulde umiddelbarhed, se David Bugge, Løgstrup og skolen (Aarhus: Klim 2014), 69-77.

6. K.E. Løgstrup, "Den 'kristne' avismand”, Information (12.5.1952).

7. Efterladt ms., XXV 3.1. (udat.), 6; cit. Bjørn Rabjerg, "Hvem er befrieren? Idealisme og realisme. Perspektiver på Platons hulelignelse hos Løgstrup og Heidegger”, Slagmark 76 (2017), under udg.

8. K.E. Løgstrup, System og symbol. Essays (København: Gyldendal 1982), 202.

9. K.E. Løgstrup, "Alvor. Opposition ex auditorio ved J.H. Schjørrings disputats", Fønix 3 (1979), 271-277 (275). 
kollega ved navn Regin Prenter) - måske mest elegant gennemført i Nationaltidende i 1941 under en titel, der taler sit eget tydelige sprog: "Den altfor korrekte Prædiken". ${ }^{10}$ Men vores meninger, understreges det i Sandager-Holevad, har intet som helst med tro at gøre; at tro på Gud er "at tage ham på ordet" (51). Hvad ingen egentlig vover; ingen er i grunden troende i denne radikale betydning. At kalde sig kristen er og bliver "humbug" (36). Med forfatterskabets senere formulering af samme pointe er der tale om, at mennesket "til stadighed reducerer til teori, hvad der skulle være tro". ${ }^{11}$

Hvad enten nu vores meninger iklædes etikkens eller ortodoksiens gevandter, er ulykken en dobbelt: Som en usynlig livvagt holder meningerne os de andre mennesker tre skridt fra livet; og med meningerne bilder vi os ind selv at sidde inde med sandheden. Og disse to ting hænger sammen; vi lukker os inde med og i os selv og blokerer for det velsignelsesrige, der kommer udefra (74). Vi træffer således dårligt nok sammen med andre mennesker, da vores forud fattede meninger - vores 'forrådssætninger' kunne vi sige med Max Frisch - blokerer for, at vi kommer ind på livet af hinanden. ${ }^{12}$ Med Løgstrups egne ord $i$ en artikel, der peger på, hvordan meningerne gør det menneskelige møde fiktivt og abstrakt: "Der fægtes med Meningerne under Abstraktion af de paagældendes konkrete Eksistens for at undgaa at faa med hinanden at gøre". ${ }^{13}$ Meninger mødes, fristes man til at sige - og alt andet end sød musik opstår! Meningerne bidrager til, at vi spærrer os inde i os selv.

I en prædiken fra 1937 benytter Løgstrup om menneskets selvindespærring følgende velvalgte illustration:

Vi lukker os inde i os selv. Som i et hus med nedrullede gardiner. Og i dette vort eget hus med nedrullede gardiner og lukkede døre, der er der også som i ethvert hus forskellige værelser til forskelligt brug. Og vi går rundt $\mathrm{i}$ værelserne, fra hovmodets værelse ind $\mathrm{i}$ bekvemmelighedens magelige stue - videre igennem fornærmethedens kammer ind i selvtil-

10. K.E. Løgstrup, “Den altfor korrekte Prædiken”, Nationaltidende (13.7.1941).

11. K.E. Løgstrup, Kunst og etik (København: Gyldendal 1961), 263.

12. Frisch efterlyser "Sätze, die nicht vorrätig sind, die einen selber noch überraschen" (Max Frisch, Aus dem Berliner Journal, udg. Thomas Strässle (Berlin: Suhrkamp 2014), 42).

13. K.E. Løgstrup, "Om Meninger”, Tidehverv 6 (1944), 69-70 (69). Jf. også Løgstrups senere polemik mod "forståelsesløse meninger", K.E. Løgstrup, Den etiske fordring (Aarhus: Klim 2010 (1956)), 36. - Vedr. Løgstrups tanker om menneskets selvindesluttethed, jf. også Bjørn Rabjerg, "Evil Understood as the Absence of Freedom", "What is Human?", red. Eve-Marie Becker m.fl. (Göttingen: Vandenhoeck \& Ruprecht 2017), 195-211. 
fredshedens stue. Frem og tilbage gennem mange andre værelser. I det hus kan der nemlig være mange værelser, de er alle små og snævre. Og alle væggene er af spejl ... (77).

Det er her, vi alle opholder os med vores meninger. Ingen kan finde ud. Ingen kan slippe ud. Som Løgstrup udtrykker det med elegant tvetydighed (tilsigtet eller ej): "vi kommer jo ikke ud af os selv" (79).

\section{Hånden}

En af de vigtigste distinktioner i Løgstrups tænkning er forskellen mellem indefra og udefra, mellem hvad der udgår fra mennesket, og hvad der kommer til mennesket. Distinktionen er afgørende for forståelsen af Løgstrups hovedtanker om kærlighedsfordringen og de suveræne livsytringer, ligesom den er en bærebjælke i hans sene metafysik. Men allerede i prædikenerne danner denne skelnen en fundamental tankefigur.

Sjældent har en teologisk-filosofisk metafor haft en sådan kraft og virkningshistorie som de berømte ord fra Den etiske fordring om, at man aldrig har med et andet menneske at gøre, uden at man holder noget af dets liv i sin hånd (Løgstrup 2010 (1956), 25). Af hensyn til vores sjælefred lukker vi ganske vist i praksis ofte øjnene for den magt, billedet blotlægger; men når håndmetaforen alligevel nyder så kolossal en popularitet, mon da ikke det hænger sammen med, at den - til trods for at den forstyrrer vores magelighed - taler til, hvad Løgstrup ynder at benævne vores 'suverænitetsvilje'? Subjektet kommer til sin ret! Måske derfor har i Løgstrup-receptionen metaforen fra hovedværket ganske overskygget den omvendte pointe: at en anden holder vores liv i sin hånd. $\mathrm{Og}$ dog er denne sidste pointe ikke mindre væsentlig i Løgstrups univers, idet den undertiden formuleres med Gud som direkte subjekt, til andre tider knyttes til de medmennesker, gennem hvis berøring Gud beriger den enkeltes liv.

Spærret inde i os selv kan vi som sagt ikke komme ud af os selv. Prædikenerne formulerer det på forskellig vis, f.eks. juleaften 1936: "Frelse os selv, det kan vi ikke. Vi kan i virkeligheden intet andet end hver dag kaste os selv i ulykke og i vild trods bekæmpe den Gud og Herre af hvem hele vort liv og vor død og vor velfærd afhænger" (28). ${ }^{14}$

14. Løgstrups pessimistiske eller (alt efter behag) realistiske antropologi fornægter sig ikke; vi genfinder den både i Den etiske fordring (f.eks. Løgstrup 2010 (1956), 161) og i den senere teori om de suveræne livsytringer, som netop kommer bag på mennesket og således ikke hidrører fra dette, men fra 'livet selv' (f.eks. K.E. 
For så vidt et udbredt dialektisk teologisk synspunkt, ikke et særsyn i samtidens prædikener. Men modsat mange andre dialektiske teologer kobler Løgstrup ikke dette med en eksistensteologisk betoning af, at mennesket så skal vælge sig selv i denne uformåenhed, hvorved hele pointen ville tabes på gulvet. Med enkelte (oftest inkonsekvente) undtagelser forfalder han ikke til forestillingen om, at det elendige menneske fra sine meningers fængsel i afmagt skal vende sig mod Gud som eneste redning. For også omvendelse, siger Løgstrup, er og bliver "humbug" (60). Derfor lader han også Gud erklære: "Og så er det jo godt, at det slet ikke er omvendelse .... der skal frelse dig - men at det er mig" (61).

I stedet betoner Løgstrup, at forløsningen må komme udefra. Det velsignelsesrige, ubekymrede liv, skriver han hen imod slutningen af sin præstegerning, kan vi kun få del i ved at blive "genstand" for det; vi kan ikke "fă det ind i os som en kilde i os selv" (269). Men denne afhængighed er netop det forunderlige i tilværelsen, hvad enten den viser sig i Guds direkte møde med mennesket, som for den spedalske, der fik livet "udefra, fra Jesu hånd" (68), eller Gud rækker os livet gennem de menneskers hånd, vi er forbundet med:

Hvad er det velsignede ved livet? At du ikke selv er herre over din glæde og din sorg. Men at andre har din glæde og din sorg, dit sinds bevægelse i sin [sic] hånd. Din ægtefælle, dine børn, dine venner - det er dem, der har dit sind, din glæde og din sorg i deres hånd. Det har du ikke selv. Et barns oplagthed gør dig glad. Mister du en af dine nærmeste, mister du noget af dig selv - din glæde, som den anden var dig - og den anden bliver din sorg. Vore tilværelser er så indfiltret i hinanden i fællesskab, at det ikke er til at rede ud (63).

Det er ikke vanskeligt at genkende grundtanken fra det, der en snes år senere skulle blive århundredets mest omtalte teologiske værk herhjemme; men pointen - billedet med hånden - er her vendt om: Min livslykke afhænger af en anden. ${ }^{15}$

Løgstrup, Etiske begreber og problemer (Aarhus: Klim 2014 (1971)), 23; jf. Bjørn Rabjergs oplysende efterskrift til samme væk).

15. Nogle få steder i Den etiske fordring fokuseres der også på den enkelte som objekt for interdependensens velsignelse, således bl.a. i kap. XII, hvor det om den forviklethed, hvoraf kærlighedsfordringen udspringer, hedder, at den tillige "er vort livs velsignelse" (Løgstrup 2010 (1956), 232). 


\section{Ekskurs: Svend Brinkmanns standpunkt}

I sit opgør med det, han rammende kalder "selvets religion", kan Svend Brinkmann med sine velgørende debatbøger Stå fast og Ståsteder på en måde siges at videreføre et løgstrupsk anliggende. Ikke mindst hudfletningen af den evindelige jagt på selvindsigt og selvudvikling og af det dertil hørende floskuløse new speak giver mindelser om Løgstrups analyse af menneskelig selvoptagethed og meningstyranni. Og i en note i den første af bøgerne påberåber Brinkmann sig da også tankerne i Den etiske fordring, ligesom han i den anden bog vier et helt kapitel til Løgstrups filosof. ${ }^{16}$

Når Brinkmann bevæger sig fra den kritiske analyse til at sætte noget i stedet, er det imidlertid ikke uproblematisk, at han påberåber sig Løgstrup. Og da hans forståelse af Løgstrup langt fra er enestående, men tværtimod må siges at være repræsentativ for store dele af Løgstrup-receptionen, kan det være på sin plads her at knytte et par bemærkninger til den. Så meget desto mere som en udryddelse af visse misforståelser faktisk vil kunne skærpe den analyse af selvcentreretheden, Brinkmann bidrager til.

I kapitlet om Løgstrup i Ståsteder skriver Brinkmann bl.a., at vi ifølge Løgstrup har "pligt til at gøre noget godt", at Løgstrup beskriver fordringen som et "etisk ideal", at "fordringen kan kaldes ... en pligt", samt at man ifølge Løgstrup "skal handle etisk, fordi det er det rigtige at gøre" (Brinkmann 2016, 108, 116, 109, 112). ${ }^{17}$

Denne karakteristik er imidlertid ikke uden vanskeligheder. Ikke blot var Løgstrup stærkt forbeholden over for 'etiske idealer' og al abstrakt tale om 'at gøre noget godt'; det flytter ifølge Løgstrup fokus fra den anden til en(s) selv og ligger således bag hans modvilje mod idealisme i enhver aftapning. ${ }^{18}$ Men nok så vigtigt i vores sammen-

16. Svend Brinkmann, Stå fast. Et opgør med tidens udviklingstvang (København: Gyldendal 2014), $156 f$ (note 86); Ståsteder. 10 gamle ideer til en ny verden (København: Gyldendal 2016), 105-116. Udtrykket "selvets religion" anvendes i Brinkmann 2014, 87.

17. Bogens ti kapitler er parallelt opbygget med en kort overskrift (Værdigheden, Løftet osv.) og et citat (motto) fra den behandlede filosof, hvori overskriftens ord indgår. Med en enkelt undtagelse: Kapitlet om Løgstrup bærer overskriften "Ansvaret” og bringer som motto håndmetaforen. Men heri indgår 'ansvar' ikke! $\mathrm{Og}$ at gøre fordringen til en fordring om ansvar frem for om kærlighed er ifølge Løgstrup problematisk, da det, som det hedder i Den etiske fordring (med slet skjult adresse til K. Olesen Larsen), "ofte nok kan betyde en akkordering med fordringen" (Løgstrup 2010 (1956), 166).

18. Modviljen kommer måske allertydeligst til udtryk i Løgstrups mesterlige analyse af Sartes skuespil Le diable et le bon dieu i Opgør med Kierkegaard (Løgstrup 2013 (1968), 86-112); jf. hertil David Bugge, Løgstrup og litteraturen (Aarhus: Klim 2009), 207-218. 
hæng er, at skønt forfatterskabets terminologi måske her undertiden kan være vildledende, var Løgstrup ikke pligtetiker. Hverken i prædikenerne eller senere. Tværtimod løber opgøret med pligtetikken som en rød tråd gennem hele Løgstrups tænkning. ${ }^{19}$

I Den etiske fordring, som er det Løgstrup-værk, Brinkmann refererer til, er det en hovedpointe, dels at fordringen fordrer at være overflødig (heraf dens absolutte uopfyldelighed som fordring), dels at den er intet mindre end en fordring om kærlighed (Løgstrup 2010 (1956), 168, 164). Fordringen fordrer med andre ord, at man u-fordret, af sig selv, drager omsorg for den, hvis liv man holder noget af i sin hånd; og dette kan kun ske adækvat i kærlighed, fordi alene kærlighed kan sanse og magte den risiko, den andens udleverethed og sårbarhed indebærer, og kun kærlighed for alvor kan mobilisere den indsigt, forståelse og fantasi, der er nødvendig i ens handlen over for den anden. Det er således ikke en handling på baggrund af pligt, der fordres, men en handling i kærlighed, som netop ikke kan fordres frem. At nedskrive fordringen til en fordring om pligt (eller ansvar) udgør for Løgstrup en akkordering med fordringen. Man skal ikke 'handle etisk, fordi det er det rigtige at gøre' men kærligt, fordi det er til bedste for den anden. Spidsformuleret: Den etiske fordring er ikke en fordring om etik! Denne dialektiske - (pligt)etikkritiske - pointe, der er bærende i hovedværket (som i det øvrige forfatterskab), og som vi snart skal vende tilbage til, kommer ikke rigtig frem hos Brinkmann. ${ }^{20}$

19. Lige så lidt var Løgstrup i øvrigt dydsetiker. At man skulle kunne "dannes i forhold til ... den etiske fordring og de suveræne livsytringer” (Brinkmann 2016, 113), rimer således dårligt med Løgstrups pessimistiske antropologi og hans gennemgående pointe, at de suveræne livsytringer ikke kan "træneres" (K.E. Løgstrup, Norm og spontaneitet (København: Gyldendal 1972), 25). - For en interessant dydsetisk kritik af Løgstrup på dette punkt, se i øvrigt Alasdair MacIntyre, "Human Nature and Human Dependence. What Might a Thomist Learn from Reading Løgstrup", Concern for the Other. Perspectives on the Ethics of K. E. Logstrup, red. Svend Andersen \& Kees van Kooten Niekerk (Notre Dame: Norte Dame Press 2007), 147-166. 20. For en udfoldelse af denne etikkritik, se David Bugge, "Hykleri eller amoral det etikkritiske spor i Løgstrups Den etiske fordring", Livskraft. Studier i kristendom, fortalling og erfaring, red. Christine Tind Johannessen-Henry m.fl. (København: Anis 2012), 147-157. - I øvrigt er det misvisende, når man ofte hører fordringen betegnet som 'det næstbedstes etik' (næstbedst i forhold til suveræne livsytringer). Nok indfanger karakteristikken fordringens erstatningskarakter; men al tale om den efterkomne fordring er og bliver illusorisk. Når Løgstrup selv en sjælden gang taler om "moral når den er næstbedst", går det da heller ikke på fordringen, men på normerne: "Svigter spontaneiteten, må man holde sig til normer" (K.E. Løgstrup, "Moral og børnebøger", Børne- og ungdomsbøger. Problemer og analyser, red. Sven Møller Kristensen \& Preben Ramløv (København: Gyldendal 1969), 19-26 (23)). 
Men ét er nu, at det på dette punkt er vanskeligt at genkende Løgstrup i Brinkmanns gengivelse. Divergensen kunne strengt taget tale i Brinkmanns favør - 'fejllæsninger' (bevidste eller ej) viser sig jo ikke sjældent bedre end forlægget. Af større interesse er derfor det alternativ, Brinkmann i debatbøgerne generelt (altså uden for Løgstrupafsnittene) skitserer til 'selvets religion'. For også med ovenstående præciseringer in mente forbliver der tydeligvis en række lighedspunkter i Løgstrups og Brinkmanns kritiske analyser af selvcentreringen. ${ }^{21}$ Så meget desto mere oplysende er det derfor at sammenholde deres respektive modsvar; for trods al affinitet er disse kun tilsyneladende identiske. Djævelen - eller evangeliet - ligger som bekendt i detaljen. Og igen synes det at være den divergerende vurdering af pligtetikken, der skiller vandene.

Som et både vittigt og tankevækkende alternativ til tidens konstante jagt på selvindsigt introducerer Brinkmann, hvad han kalder "selvudsigt". Og midlet hertil er en række ståsteder, som vi bør øve os i at stå fast på, hvorved livet viser sig som meningsfuldt. Det med meningsfuldhed sammenfatter Brinkmann bl.a. i ordene om, at det væsentlige i livet er "at gøre sin pligt", samt at det er "meningsfuldt at ville være et godt menneske - også selv om det eventuelt måtte kollidere med ens subjektive velbefindende" (Brinkmann 2016, 38; 2014, 21; 2016, 185).

Spørgsmålet er dog, om ikke Brinkmann her utilsigtet nærmer sig det, han ellers gør op med. Nissen (selvet) flytter med! Hvilket igen skyldes den stærke pligtetiske betoning af subjektet, der, set med løgstrupske briller, prisgiver sansen både for umiddelbarheden, for det, vi kunne kalde kærlighedens radikale interdependens (vort liv er falles lyst), og for den udefra kommende forløsning.

I Løgstrups øjne er således enhver pligtetisk tanke en bagtanke, belagt med selvfordoblingens smittekim ('at ville være et godt menneske'); dén "instrumentalistiske" hang til selv at ville 'have noget ud af det', som Brinkmann kritiserer, rammer også pligtetikken. Besindelsen på pligten formår ikke at "blokere for en navlepillende refleksionssyge" (Brinkmann 2016, 40, 154), men sublimerer blot denne, på bekostning af umiddelbarheden. ${ }^{22}$

21. På det samfundsanalytiske plan kunne man ligeledes pege på en række interessante berøringsflader, der kunne fortjene en yderligere undersøgelse, f.eks. mellem Brinkmanns begreb 'den accelererende kultur' (Brinkmann 2014, 31) og Løgstrups udtryk 'den akkumulerende kulturoverlevering' (K.E. Løgstrup, Solidaritet og karlighed og andre essays (København: Gyldendal 1987), 49) eller mellem Brinkmanns forsvar for ritualiserede omgangsformer (Brinkmann 2014, 75f) og Løgstrups analyse af 'formløshedens tyranni' (Løgstrup 1961, 111).

22. Jf. K.E. Løgstrup, "Enhver moralsk Tanke er en Bagtanke”, Menighedsbladet 25 (1936), 429-438. 
Endvidere er ifølge Løgstrup det, der bærer oppe i tilværelsen, ikke pligten, men tværtimod den kærlighed, der, som det hedder i prædikenerne, elsker af hjertets lyst (184, 199). For hvor kærlighed råder, hvor den ene i sandhed er betænkt på den andens ve og vel, er der ingen kollision mellem 'ens subjektive velbefindende' og hensynet til den anden, mellem "egenkærlighed og næstekærlighed" (191). Eller med terminologien fra hovedværket: Ikke blot er det $i k k e$ en handling af pligt, der fordres; det fordres ligefrem, at man af lyst (i kærlighed) drager omsorg for den anden. Derfor ses også naturlig kærlighed, som den f.eks. kunne ytre sig hos forældre, som en prototype for sand kærlighed (Løgstrup 2010 (1956), 162-163). ${ }^{23}$

Endelig er for Løgstrup tanken om fra meningernes fæstning at kunne nå til selv-udsigt - om ikke en total illusion, så i hvert fald langt fra det forløsende i tilværelsen. For Løgstrup drejer det sig derfor ikke om ståsteder, hvor $v i$ skal stille $o s$, men om, at nogen udefra træder ind på vores enemærker og overraskende river os ud af os selv.

Disse tre fænomener - umiddelbarheden, kærlighedens radikale interdependens samt forløsningen udefra - strejfes faktisk i Brinkmanns debatbøger. I en analyse af håndmetaforen hedder det f.eks., at Løgstrup med denne formår "at pege på en form for umiddelbarhed i vores liv"; i kapitlet om Iris Murdoch henledes tilsvarende opmærksomheden på kærlighedens "selvoverskridende opmærksomhed på en anden”; og endelig fremhæves i et afsnit om 'illusionsløs litteratur' det "væsentlige ved alt det, der ligger uden for selvet" (Brinkmann 2016, $115,129 ; 2014,114)$.

Og ligesom de førnævnte præciseringer af Løgstrups position reelt skønnes at kunne styrke Brinkmanns kritiske ærinde, er det spørgsmålet, om det ikke også snarere var ved en dyberegående undersøgelse og fremhævelse af disse fænomener - frem for af pligten -, Brinkmann fremover skulle hente skyts i sin analyse af 'selvets religion'.

Og i det løgstrupske univers hænger de omtalte fænomener tilmed sammen: Ramt af den udefra kommende lystbårne, spontane kærlighed behøver (og kan) man slet ikke omvende sig eller stå fast. Subjektets selvfordoblende optagethed af, hvad det skal mene, hvordan det skal vende sig, og hvordan det skal stille sig, er erstattet af, at det

23. Løgstrup ville således uden vanskeligheder kunne gøre Schillers anti-kantianske, satiriske digt til sit: "Gerne dien ich den Freunden, doch tu ich es leider mit Neigung, / Und so wurmt es mir oft, daß ich nicht tugendhaft bin. // Da ist kein andrer Rat; du mußt suchen, sie zu verachten, / Und mit Abscheu alsdann tun, was die Pflicht dir gebeut" (Friedrich Schiller, Sämtliche Werke, bd. I (München: Carl Hanser Verlag 1958), 299f). Mere elegant kan forsvaret for kærlighedens umiddelbare og radikale interdependens næppe serveres. 
allerede har fået, har modtaget. Stå-steder er erstattet af fä-steder. Vel at mærke få-steder, man ikke forud kan lokalisere.

\section{Selvhævdelsen}

Løgstrups kritik af pligtetikken blotlægger imidlertid en mere generel og fundamental tendens i mennesket: vores selv-hævdelsestrang i dette ords egentligste forstand. Og som vi allerede har berørt, ytrer denne trang sig på to måder, der tilmed er intimt forbundne: Når vi handler, fordobler vi typisk - selvspejlende - vores jeg, til forskel fra spontanitetens selvforglemmelse. Og når der omvendt handles mod os, vægrer vi os ofte ved blot at modtage, blot at få. Vi vil os selv $-o g$ vi vil selv!

Prædikenerne udtrykker det på forskellig vis, og ikke sjældent er det vores farisæisme, der må holde for. Hvad angår fordoblingen, baner den stadige insisteren på dikotomien mellem egen- og næstekærlighed samt fremhævelsen af 'pligt' på bekostning af 'tilbøjelighed' ikke blot vejen for "denne skrækkelige fromhed, der altid har hovedet kælent på skrå” (185). Den afstrejfer tilmed det bærende i Jesu tale om næstekærlighed: "Velgerninger mod et andet menneske, der sker i en selvovervindelse, afskyr han". Ved nærmere eftersyn er selv-overvindelsen jo alt andet end u-selvisk; det konstante subjekt for overvindelsen er ingen ringere end - mig selv. Selvovervindelsen er og bliver derfor "ufrugtbar", ligesom dens gerninger er "golde" for dem, de tager sigte på (190).

Den modsætning, Jesus går ud fra, er i det lys aldrig en "moralsk" (som den mellem egen- og næstekærlighed), men derimod modsætningen mellem "liv og død" i dette ordpars videste betydning (191). Når Guds rige bryder igennem, midt i vores hverdag, er det således altid drevet af lyst $(184,201,270)$. Som det er tilfældet med den barmhjertige samaritan; han "overvinder ikke sin egenkærlighed, dertil er hans hjælp altfor selvfølgelig” (190). Eller som det er tilfældet med lignelserne om hyrden og kvinden; modsat farisæerne, som i deres påpasselighed mener at have "fået livet til at passe på jeget med", glemmer de alt om sig selv i deres søgen efter fåret og drakmen: "Livet sluger jeget, barmhjertigheden sluger jeget" (198f).

Derfor er også ethvert forsøg på at efterligne Jesus - ham, der "intet jeg" havde (153) og "var fremmed for denne besynderlige interesse i den egen moral, og for al den selvspejling, den gav anledning til" (56) - dømt til at mislykkes: "Vi gør dårligt i at tage Jesus som forbilled ... for vi bliver kun hyklere deraf" (134). Hyklere, fordi efterfølgel- 
sesforsøget i sagens natur implicerer en jeg-fokusering, og fordi vi på den anden side, som de moralske mennesker vi nu engang er, ikke vil vedgå forsøgets uundgåelige fallit. Vores moralske tænkemåde driver os således ud i hykleriet. Med en prægnant formulering fra Den etiske fordring: "Er et menneske ikke hyklerisk, er det amoralsk" (Løgstrup 2010 (1956), 175). ${ }^{24}$

Denne fordoblingens (moralske) hævdelse af subjektet korresponderer som sagt med vores hyppige vægring ved blot at være objekt for det velsignede, der rammer os udefra. Som det hedder i en prædiken fra 1941, hvor den kommende fænomenolog skelner mellem en fremtidsrettet forflygtigelse af nuet og forventningens intense nærvær: Vi lever, som om livet "først skulle blive noget værd ved det, vi får ud af det med al vor virken". Som ren gave vil vi ikke modtage livet; vi har - med en variant af en åbenbart ret elastisk metafor - "taget det i vor egen hånd” (209). Som farisæerne bilder vi os ind, med de føromtalte handlinger og meninger, selv at sidde inde med nøglen til vores livslykke.

Og hverken farisæismen i den ene eller den anden form - hverken forgabelsen i eget jeg eller ubehaget ved at blive sat fra roret - eksternaliseres i prædikenerne; tværtimod understreges det om reaktionen på Jesu forkyndelse, at vores bagklogskab på ingen måde berettiger os til at "hæve os over hans jødiske samtidige" (254). Homo faber, den selvberoende, altkontrollerende 'menneske-smed', der senere i forfatterskabet skal dukke op i talrige (litterære) varianter, er tilsyneladende ikke blot en epokal skikkelse, men repræsenterer et mere grundlæggende træk i menneskets natur.

Kristendommen bryder med - eller rettere: overbyder - denne menneskelige selvhævdelse, også i dens religiøse varianter. Evangeliet møder det nøgne menneske, sådan som det er under alle de alvorstunge meningers hylstre, hvor der ingen individuelle forskelle er, "ingen forskel på ond og værre" (55), "ingen forskel på den hæderlige

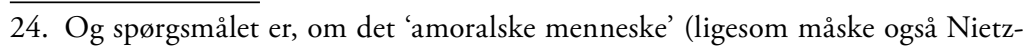
sches 'overmenneske') giver mening som andet end et grænsebegreb! - I en vis forstand er den skarpe sondring mellem pligt og lyst i øvrigt misvisende, uanset pligtens valorisering. Som Løgstrup gør opmærksom på i System og symbol, ligger der, når jeg af pligt gør den gerning, der er forbundet med ulyst, under ulysten en dybere lyst. Hans eksempel genkender vi nok alle, når vi, trods alt, vælger at forlade morgenlejets varme dyner: "Neden under ulysten til at stå op må der være en dybere lyst til i tide at være på sit arbejdssted” (Løgstrup 1982, 171). Tilsvarende peger Løgstrup i en leksikonartikel på tilbøjeligheden (Neigung) til at handle i overensstemmelse med pligten (K.E. Løgstrup "Pflicht", $R G G$, 3. udg., bd. 5, red. Kurt Galling \& Hans von Campenhausen (Tübingen: Mohr 1961), 313-317 (315)). Jf. hertil David Bugge, Hinandens verden. Ledsager til K.E. Løgstrup: Den etiske fordring (Aarhus: Klim 2011), 157f, 182. 
borger og morderen" (133). Som Løgstrup udtrykker samme pointe i slutningen af sit forfatterskab, er i kristendommen kun én ting af virkelig alvor: Jesu udsagn om, at fortabelsen vendes til frelse; hvilket Jesus selv drog konsekvensen af, idet han "nivellerede fortabelsen" og her ophævede alle gradsforskelle (Løgstrup 1979, 274). Eller med formuleringen godt 40 år tidligere i en prædiken, som Løgstrup selv har givet titlen "Åbenbaring": Der er tale om en barmhjertighed, der "rydder al vor pynt, alle vore undskyldninger, alle vore meninger, al vor ejendom til side ..., der er så rig, så den intet kender til alle de forskelle, som vi ustandseligt bygger op mellem os ..., der river alle forskellenes mure ned" (57).

For dén barmhjertighedens gave, Løgstrup her omtaler, er i enhver henseende ufremtvingelig. Den er ikke givet af pligt, for en gave givet af pligt er ikke en gave, men hykleri (270). Og den er heller ikke givet, for at der skal vises taknemmelighed, for hvis giveren har bagtanker om taknemmelighed, giver han slet ikke (111). Den er derimod den sande - og suveræne - karlighedsytring. Som Jesus rask væk tilgav de mennesker, han mødte, "uden først at tage mål af deres anger og bod” (33), er der tale om en frelsende kærlighed, der, med Løgstrups formulering i den allerførste prædiken (1936), "ikke engang lader sig standse af, at de hvem kærligheden gælder vægrer sig ved at tage imod den"; det er en kærlighed, der "gælder - endog i deres protest" (18). Eller med ordene et lille årstid senere: Det er "en barmhjertighed, der er så dyb, at den ikke hindres af, at de mennesker, den gælder spotter dens eensidighed, skønt eensidigheden er deres frelse" (44). Med et spil på Løgstrups senere udtryk kunne vi passende kalde dette for nådens ligeløb.

Af os selv kommer vi ikke ud. Kun når denne ensidige nåde "vil ramme vort eget tillukkede hus ... som lyn”, slipper vi ud af vores selv-indespærring. Først da frisættes vi fra den evige selvbetragtning, først da befries vi for alvor fra os selv. ${ }^{25}$

25. Denne radikale soteriologi, der - renset for selv den mindste synergisme - korresponderer med Løgstrups antropologi, står i (uformidlet og ufrugtbar) modsætning til visse steder i både prædikenerne og det senere forfatterskab. I en prædiken fra 1937 hedder det f.eks., at der "kun er een måde at være uværdig på, og det er at tvivle på - at barmhjertigheden er betingelsesløs" (46) - en formulering, der om ikke dekonstruerer sig selv, så i hvert fald må siges at være noget selvmodsigende (kun een - betingelsesløs). Et utvetydigt skred støder man på i Skabelse og tilintetgørelse med den påstand, at den guddommelige tilgivelse afhænger af syndserkendelse og anger: "Jesus kendte til indignation, det viser hans straffetaler over farisæerne. Men efter beretningerne at dømme, så snart ugerningsmanden så sin forbrydelse i øjnene og fortvivlede, og så snart moralisten så sin selvophøjelse og sin underkuelse af de andre i øjnene og angrede, vendte hans indignation sig til tilgivelse, og det spontant" (K.E. Løgstrup, Skabelse og tilintetgørelse (Aarhus: Klim 2015 (1978)), 


\section{En anden(s) stemme}

Spørgsmålet er, om det ikke snarere var dette fordoblende, selvberoende subjekt, Løgstrup skulle have koncentreret sine opgør med Kierkegaard om - frem for om den misforståede påstand, at Kierkegaard var en verdensforsagende pietist. For med blikket for den (eksklusivt) udefra kommende forløsning er forskellen til i hvert fald én tendens og konsekvens hos Kierkegaard (den, der kunne sammenfattes i det subjekt-tyngede udtryk 'troens spring') til stede hos den unge Løgstrup, længe inden hans brud med Kierkegaards disciple. ${ }^{26}$ Men lad os alligevel til slut vende blikket mod en sådan discipel (om end en noget vrangvillig en af slagsen) for at vise, at den virkelige, velsignelsesrige sandhed ogsa her uventet kan bryde frem.

Henrik Ibsen skal engang have erklæret, at hvis man satte ham på et skafot, og det gjaldt hans hoved, og man da spurgte ham, om han havde læst Søren Kierkegaard, da måtte han svare nej. Nu er Ibsen ikke nødvendigvis den bedste kilde til Ibsen; med Brandes som tidens selvudnævnte højesteretsdommer var det næppe problemfrit at vedgå sin åndelige gæld til hosekræmmerens søn. Og ikke mindst Ibsens hovedværk Peer Gynt er og bliver, som det ofte er blevet godtgjort, helt ned i ordvalget kierkegaardsk i sit menneskesyn. Det gælder i udstillingen af æstetiker-tilværelsens luftige og uforpligtende drømmeri; og det gælder i den stadige tematisering af, at man må finde sig selv - frem for på troldevis at være sig selv nok og frem for at have et skiftende, hypotetisk selv. Fra først til sidst er stykket kierkegaardsk i sin ånd. Eller måske netop ikke fra først til sidst. For til allersidst bryder en helt anden stemme ind - og bekræfter reglen om, at værket undertiden er klogere end forfatteren.

Knappestøberen har (i femte og sidste akt) opsøgt Peer og stillet ham i udsigt, at han skal støbes om; for han har livet igennem hverken været kold eller varm, han har ikke været sig selv. Peer søger nu at finde forskellige vidner, der kan redde ham fra støbeskeen, men forgæves; fortvivlet må han sande, at han er udstødt af selvejeradelen.

Som en sidste desperat udvej opsøger Peer da Solveig - kvinden, som han har svigtet mere end nogen anden - for at få hende til at bekræfte et stort synderegister, så han i det mindste ikke kan kaldes lunken:

315, jf. 312). Med en sådan 'betinget spontanitet' synes en - ikke helt ubetydelig pointe fra prædikenerne at være gået i glemmebogen.

26. For et forsøg på en sådan kritisk (løgstrupsk) korrektion af Løgstrups Kierkegaard-kritik, se Bugge 2011, 284-289. 
Så sig, hvad du ved!

Hvor var jeg, som mig selv, som den hele, som den sande?

Hvor var jeg, med Guds stempel på min pande?

Men Solveig ser tværs igennem Peers (og Knappestøberens (og Ibsens (og Kierkegaards))) bogstaveligt talt selv-centrerede system og svarer "I min tro, i mit håb og i min kærlighed". ${ }^{27}$

Peer Gynt befries udefra for den evindelige jagt på det sande selv og aflastes fra fordoblingens optagethed af, hvordan han skal vende sig og stå. En anden er brudt ind i hans hus med de nedrullede gardiner, og først nu er glæden - med Løgstrups ord i prædikenerne - "virkelig glæde" (124). Selv drømmen, der ellers stykket igennem er blevet mistænkeliggjort, bliver på denne baggrund tilladt. Solveigs (og stykkets) sidste replik kommer således samtidig til at danne en ny begyndelse:

Jeg skal vugge dig, jeg skal våge; -

sov og drøm du, gutten min! (Ibsen 1867, 263).

Og drøm! En anden holder Peers liv i sin hånd. Og i dette lys kan han uhindret hengive sig til drømmen - det stof, meninger i sidste ende er gjort af - og vende og stille sig, på hvad måde det skal være. Men nu befriet fra den patos, der tillægger meningerne (og standpunkterne) en dybere mening.

Solveig har for længst fundet sin drakme.

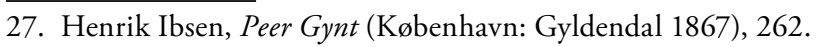

